\title{
Respiratory Monitoring in Pediatric Neuromuscular Disease
}

\section{Andre Sugiyono $^{1}$, Siti Chandra Widjanantie ${ }^{2}$}

${ }^{1}$ Department of Physical Medicine and Rehabilitation, Universitas Indonesia, Cipto Mangunkusumo General Hospital, Jakarta, Indonesia.

${ }^{2}$ Department of Physical Medicine and Rehabilitation, Universitas Indonesia, Persahabatan General Hospital, Jakarta, Indonesia

\begin{abstract}
Neuromuscular disease in childhood result in dysfunction of chest wall and lung movement that interfere ventilation function and gas exchange. Without vital respiratory pump, ventilation, gas exchange function and cough ability would be compromised and could result in complications such as pneumonia, atelectasis, and respiratory failure.

Comorbid factors in cardiovascular, musculoskeletal, nutrition, and gastrointestinal could aggravate respiratory morbidity and mortality if not adequately treated. This paper was written to review anatomy and physiology of neurorespiratory system, pathophysiology of respiratory complication in neuromuscular disease, clinical assessment and respiratory monitoring of childhood neuromuscular disease from Physical Medicine and Rehabilitation point of view.
\end{abstract}

Keywords: assessment, neuromuscular disease, pediatric, respiratory, ventilation

\begin{abstract}
ABSTRAK
Penyakit neuromuskular pada masa kanak-kanak mengakibatkan disfungsi dinding dada dan pergerakan paru yang mengganggu fungsi ventilasi dan pertukaran gas. Tanpa pompa pernapasan vital, ventilasi, fungsi pertukaran gas dan kemampuan batuk akan terganggu dan dapat mengakibatkan komplikasi seperti pneumonia, atelektasis, dan gagal napas.

Faktor komorbid pada kardiovaskular, muskuloskeletal, nutrisi, dan gastrointestinal dapat memperburuk morbiditas dan mortalitas pernapasan jika tidak ditangani secara memadai. Makalah ini ditulis untuk meninjau anatomi dan fisiologi sistem neurorespirasi, patofisiologi komplikasi pernapasan pada penyakit neuromuskular, penilaian klinis dan pemantauan pernapasan penyakit neuromuskular anak dari sudut pandang Kedokteran Fisik dan Rehabilitasi.
\end{abstract}

Kata Kunci: pediatrik, penilaian, penyakit neuromuskular, pernapasan, ventilasi 


\section{INTRODUCTION}

Correspondent Details:

\section{Andre Sugiyono}

Email: andre.physiatrist@gmail.com

Department of Physical Medicine and

Rehabilitation, Faculty of Medicine,

Universitas Indonesia,

Dr. Cipto Mangunkusumo Hospital,

Jakarta, Indonesia
Neuromuscular disease (NMD) are a broad group of disease that include dysfunction of the peripheral nerves and muscles including anterior horn cells, peripheral nerve, neuromuscular junction and muscles. Etiology could be genetic or acquired defects with manifestation from age six month or less to adolescence. One of the most common childhood NMD are spinal muscular atrophy (SMA) and Duchene Muscular Dystrophy (DMD). Motor defect causes muscle weakness and atrophy on the extremities, respiratory system, swallowing and mastication muscle. Developmental delay or milestone regression is also a common presentation. ${ }^{1}$

Table 1. Classification of neuromuscular disease

\begin{tabular}{|c|c|c|}
\hline Neuromuscular Disease & Location & Common Disease \\
\hline Motor neuron disease & $\begin{array}{l}\text { Lower motor neuron and sometimes } \\
\text { upper motor neuron }\end{array}$ & $\begin{array}{l}\text { Amyotrophic lateral sclerosis } \\
\text { Spinal Muscular Atrophy }\end{array}$ \\
\hline Peripheral Neuropathy & Peripheral nerve system & Charcot Marie Tooth Disease \\
\hline Neuromuscular junction & $\begin{array}{l}\text { Transmission signal for muscle } \\
\text { contraction is impaired }\end{array}$ & Myasthenia Gravis \\
\hline Myopathy & $\begin{array}{l}\text { Impaired maintenance and repair of } \\
\text { muscle tissue }\end{array}$ & $\begin{array}{l}\text { Becker muscular dystrophy } \\
\text { Duchene muscular dystrophy } \\
\text { Congenital muscular dystrophy }\end{array}$ \\
\hline
\end{tabular}

The cause of morbidity is multifactorial includes respiratory and bulbar muscle weakness, hypotonia, skeletal deformity, and interrelated comorbidities (malnutrition, cardiovascular, and gastrointestinal disorder). Respiratory complication may arise such as recurrent infection, sputum retention, atelectasis, aspiration, sleep disordered breathing (SDB), hypoventilation, and respiratory failure. Holistic and comprehensive care is necessary for early prevention and adequate management. Progressive development of treatment over past few decades has significantly increased the life expectancy and decreased complication. 2 The review article was created by searching literature from pubmed.gov with the keywords "respiratory", "assessment", "pediatric", "neuromuscular disease". 


\section{Physiology of ventilation and neuromuscular respiratory control}

Ventilation is process of air exchange between atmosphere and lung. Air will move from higher to low pressure. Inspiration occurs due to decrease intrathoracic pressure and increase thorax volume. Enlargement of thoracic cavity facilitated by inspiratory muscle contraction i.e. diaphragm and external intercostal muscles. Meanwhile, expiration is a passive process of lung and chest wall recoil. How intrathoracic pressure swings and triggers movement of air is called respiratory pump. Contraction of these muscle is regulated by respiratory centers in medulla oblongata and pons. Medulla respiratory center exerts impulses to inspiratory muscle and trigger inspiration while pontine respiratory center is active during inspiration and expiration and modified breathing rhythm during activities. They receive input from chemoreceptor in medulla and peripheral (carotic and aortic body) which detect changes of blood $\mathrm{PaO}_{2}$, $\mathrm{H}+$, and $\mathrm{PaCO}_{2}$. Frequency and depth of breath are controlled to maintain homeostasis based by these input. ${ }^{3}$

Wakefulness state is activated by ascending reticular activating system (ARAS). During sleep state, ARAS inhibition occurs causing changes in brain waves. Electroencephalography examination reveal sleep process divided into rapid eye movement (REM) and non-REM (NREM) phases. Respiratory physiological differences such as atonia of upper airway, intercostal muscle and to lesser extent on diaphragm is more prominent in REM phase. Alveolar ventilation is decreased to $1-2 \mathrm{~L} / \mathrm{min}$ due to decrease in tidal volume with a shallow and irregular breathing pattern during sleep.
There is also decreasing responsiveness of respiratory center with decreasing respiratory rate. Inspiration will depend almost entirely on the diaphragm. Atonia of upper airway muscles increases airway resistance. The recumbent position will also reduce the functional residual capacity (FRC). There is physiological $\mathrm{PaO} 2$ decrease $3-10 \mathrm{mmHg}$ and $\mathrm{PCO}_{2}$ increase $2-8 \mathrm{mmHg}$ during sleep. ${ }^{4}$

\section{Pathophysiology of Respiratory} Complication in Neuromuscular Disease Muscle group dysfunction is divided into 3 types: ${ }^{5}$

1. Impaired respiratory pump due to dysfunction of inspiratory muscles

2. Upper airway disorder and swallowing dysfunction (upper airway muscle disorder)

3. Impairment of cough (dysfunction of inspiration, expiration, and upper airway muscles)

Based on the concept of respiration pump, respiratory capacity is decreased by neuromuscular weakness. On the other hand, pump workload from mechanical changes such as decreased lung compliances, chest wall stiffness, and microatelectasis. Decrease sensitivity of peripheral and central chemoreceptor due to direct damage to respiratory center cause incompensation of central respiratory drive. ${ }^{6}$

Physiological changes during sleep will lead to greater respiratory demand. Upper respiratory muscles weakness leads to increase airway obstruction in combination with reduced intercostal strength and diaphragm could lead to hypoventilation. Hypoventilation occur firstly during REM sleep to entire sleep phase and finally diurnal. ${ }^{7}$ 


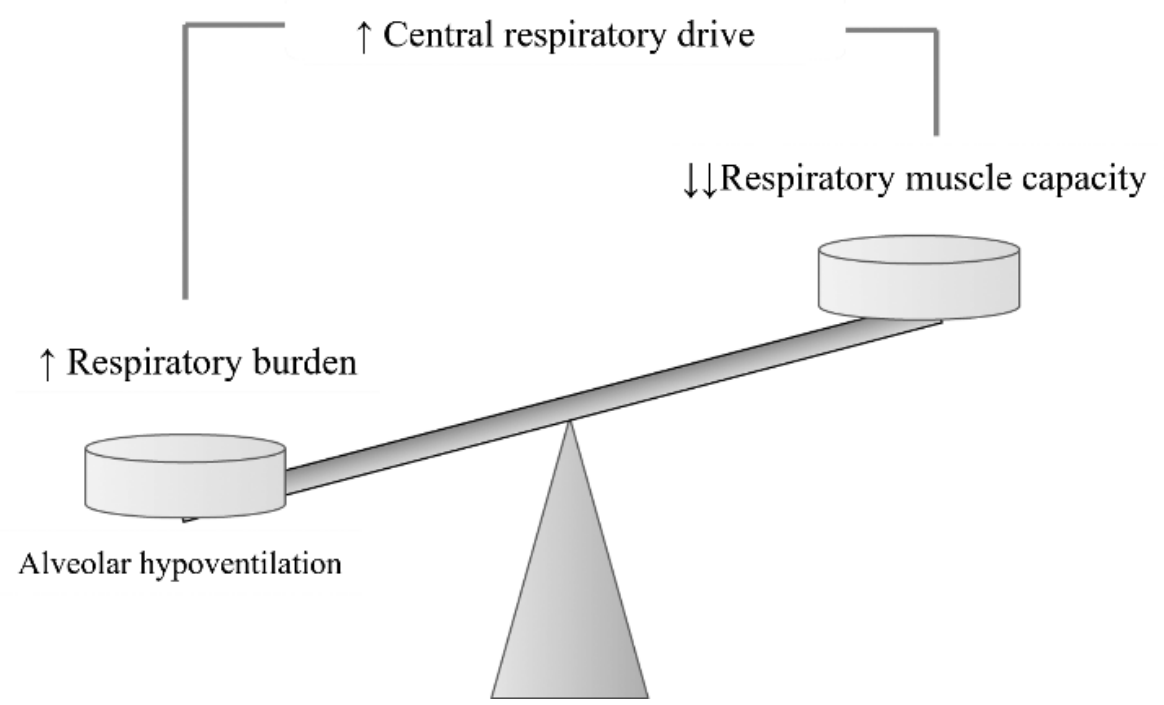

Figure 1. Balance between respiratory muscle capacity and respiratory load controlled centrally

Impaired cough function leads to susceptibility to infection and microatelectasis. Normal cough requires recruitment of $85-90 \%$ of lung volume, and glottis competence to close to compress air and open for expulsion. ${ }^{5}$

\section{Factors affecting respiration morbidity and mortality}

During its disease course, respiratory condition affected by musculoskeletal, cardiovascular, nutritional, swallowing, and gastrointestinal disorder.

Most common musculoskeletal problem that affect respiratory system are progressive kyphoscoliosis and chest wall deformities. Kyphoscoliosis occurs in $70-90 \%$ patients with DMD and all children with type 1 and 2 SMA due to paraspinal muscle weakness and muscle imbalance. It may appear in infancy but critical points occur during puberty or when child is nonambulatoric as in DMD. Improper bracing can further restrict breathing. Kyphoscoliosis result in suboptimal insufflation volume, asymmetric breathing, increase dead space, reduced lung and chest wall compliance. Pulmonary hypoplasia may occur in younger children. ${ }^{8}$ Chest wall deformities i.e. bell-shaped chest deformity and pectus excavatum occur in type 1 and 2 SMA population especially one with paradoxical breathing. It is caused by more severe intercostal muscle involvement with relative diaphragm sparing. ${ }^{9}$

Cardiac complications closely related to respiration and are the second leading cause of death in DMD. Conduction disorder and cardiomyopathy may occur and cause heart failure. Decompensated heart failure will increase fluid extravasation in lung, decreased lung volume, and increased airway resistance. Spirometry reveal mixed obstructive-restrictive pattern with bronchial hyperresponsiveness. Otherwise during pneumonia or blood gas abnormalities, a reversible decrease in ejection fraction occurs. Compensation through ventricular dilatation occur with concomitant increase in myocardial wall stress, oxygen demand, and arrhytmogenicity. ${ }^{8}$ 
Nutritional problem such as undernutrition and obesity may occur. Mostly have low lean body mass, protein and minerals. Undernutrition will deteriorate respiratory muscles and diaphragm strength. Immunodeficiency renders patient susceptible to recurrent infection. In contrary, obesity occurs in $54 \%$ of NMD patients aged 7-13 years due to low physical activity, steroid use, and decrease muscle mass which reduced BMR. Obesity affect ventilation dynamics, deteriorates SDB, immobilization and increase risk of pressure ulcer. ${ }^{8}$

NMD may cause dysphagia as well as affect gastrointestinal motility. Disturbances range from masticatory problems, post swallowing residue and aspiration. ${ }^{10}$ Postural factors such as reduced cervical ROM from spinal instrumentation, and neck instability due to neck flexor weakness result in hyperextended position during swallowing. Tracheostomy can cause dysphagia and acid reflux. GERD need to be aware especially in non-ambulatory children. Aspirate material can be saliva, oral bacteria, or gastric contents. Lung inflammation, infection, bronchiectasis and lung fibrosis may occur. ${ }^{11}$

\section{Clincal Examination of respiratory system in NMD}

Management of neuromuscular respiration is carried out in a multidisciplinary manner according to the progression of each neuromuscular disease. Pulmonary function assessed periodically in all patients with or without symptoms and took into account all other comorbidities. ${ }^{6}$ DMD Care Consideration (2018) published assessment and respiratory management in DMD according to phase of disease course. Comprehensive respiratory assessment consists of spirometry, sleep study, cough function, respiratory muscle strength, and gas exchange assessment are mandatory in early non-ambulatory phase at least every 6 months. $^{12}$

1. Respiration: clinical, radiographic, pulmonary function test, blood gas analysis, spirometry, peak cough flow, MIP, MEP, SNIF, and night study (pulse oximetry, PSG). Optional: supine test, lung volume, diffusion

2. Dysphagia assessment: clinical, screening test, videofluoroscopy

3. Cardiovascular assessment (if relevant)

1. Slowly progressive neuromuscular disease

- Follow up every 6-12 months

- Evaluation of symptoms, spirometry, BGA, SNIF/MIP/MEP, pulse oxymetry

2. Rapidly progressive neuromuscular disease

- Follow up every 2-4 months

- Evaluation of symptoms, peak cough flow, BGA, SNIF, pulse oxymetry

Figure 2. Evaluation and respiratory monitoring in NMD. ${ }^{6}$ MEP: maximal expiratory pressure, MIP: maximal inspiratory pressure, PLSG: polisomnografi, SNIF: sniff nasal inspiratory force. 


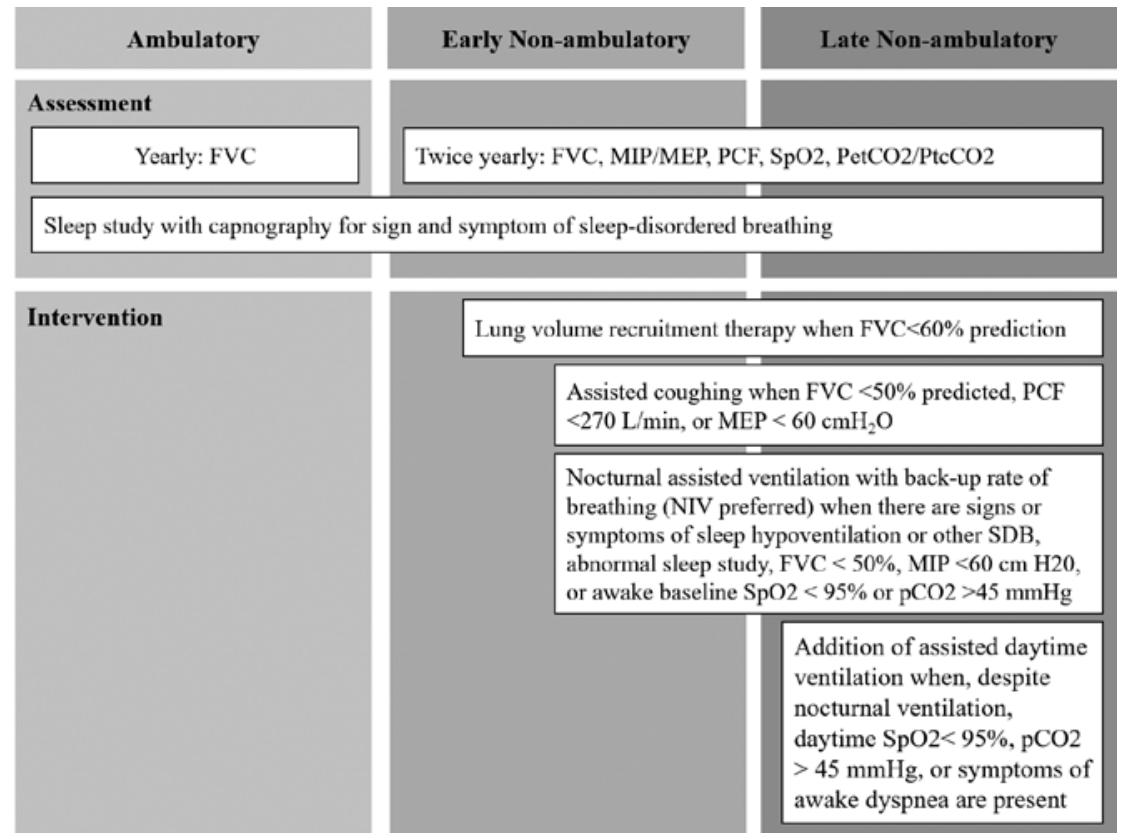

Figure 3. Respiratory Monitoring in DMD ${ }^{12}$

International standard of treatment for SMA emphasize different focus of respiratory evaluation for each type of SMA. Type 1 SMA (non-sitter) who have the highest risk of respiratory complication are recommended to be evaluated every 3 months for ventilator disturbance with pulse oximetry and capnography. Sleep study was performed in all patients if there was a slightest suspicion of hypoventilation. Airway clearance technique with mechanical insufflation-exufllation is given to all patients proactively. In type 2 SMA (sitter), clinical evaluation and spirometry is recommended every 6 months. Sleep study recommended when patient exhibit symptoms of nocturnal hypoventilation. For type 3 SMA (walker), PFT were mostly normal with minor decrease over 4-year observation. ${ }^{13}$

Signs and symptoms can be non-specific at an early stage. Shortness of breath initially occur during activity follow by dyspnea at rest. Diaphragm weakness cause position-related symptoms such as orthopnea, dyspnea during forward bending position or body immersion. Symptoms of SDB need to be anticipated in the form of night symptoms (frequent awakening, snoring and apnea) or daytime symptoms (morning headache, fatigue, and hypersomnolence). ${ }^{14}$

Physical examination includes posture, appearance and affect. Patients may appear tired and have difficulty concentrating. Vital sign shows rapid and shallow breathing. Evaluate accessory muscle use or certain position such as tripod that increase mechanical advantage of breathing muscle. Examination of chest expansion performed in supine at xiphoid. Cough examination carried out by asking patient to cough and assess strength, audibility, and effectiveness in clearing secrets. ${ }^{2}$

Respiratory examination during sitting and supine can provide valuable information. In a supine state, patient may show signs and symptoms of increased dyspnea or characteristic paradoxical breathing. Paradoxical movement of chest and abdominal indicate decompensated respiratory pump and sign of diaphragmatic weakness. Abnormalities can vary from asynchronous breathing to prominent paradoxical movement in inspiratory phase. Paradoxical breathing can occur in any patient with a swing of inspiratory intrathoracal pressure of more than $30 \% .{ }^{14}$ 
Instrumental assessment of neuromuscular respiration Pulmonary Function Test

Spirometry is mandatory evaluation for NMD. Other measurement such as measurement of residual volume (RV), functional residual capacity (FRC), and total lung capacity (TLC) are important but are not always available. Vital capacity (VC) is mostly used to monitor disease progression. ${ }^{7}$ Vital capacity is decreased during supine from decrease mechanical effectiveness of diaphragm in supine. Decrease $\mathrm{VC}>25 \%$ in the supine than sitting has a sensitivity of $90 \%$ and $79 \%$ for diagnosing diaphragmatic weakness as a precaution for hypercapnic respiratory failure. However not all NMD is the same. In SMA, diaphragm is relatively spared thus decrease in FVC is found with no positional difference. ${ }^{7}$

Spirometry examination may be started in children $>6$ years old by taking into account factors such as cognitive, cooperation, and patient weakness. The use of slow vital capacity maneuver facilitates measurement in weaker subjects by using slow exhale maneuver. Flat mouthpiece or facemask with tight fixation may be done for patient with facial muscle weakness. ${ }^{11}$

Table 2. Clincal correlation of vital capacity in pediatric neuromuscular disease

\begin{tabular}{|c|c|c|}
\hline Study & Participant & Clinical correlation of Vital Capacity (VC) \\
\hline \multirow[t]{3}{*}{ Ragette et al ${ }^{15}$} & Primary myopathy & - $\mathrm{VC}<60 \%$ predict onset of SDB $(\operatorname{Sn} 91 \%$, Spe $89 \%)$ \\
\hline & & $\begin{array}{l}\text { - } \mathrm{VC}<40 \% \text { predict continuous nocturnal } \\
\text { hypoventilation }(\mathrm{Sn} 94 \% \text {, Spe } 79 \% \text { ) }\end{array}$ \\
\hline & & $\begin{array}{l}\text { - } \mathrm{VC}<25 \% \text { predictive with diurnal ventilatory failure } \\
(\mathrm{Sn} 92 \% \text {, Spe } 93 \%)\end{array}$ \\
\hline \multirow[t]{2}{*}{ Schwake et al ${ }^{16}$} & $\begin{array}{l}45 \text { NMD patient } \\
\text { (SMA, DMD, } \\
\text { muscular dystrophy } \\
\text { etc) }\end{array}$ & $\begin{array}{l}\text { VC was the strongest predictor of detecting number } \\
\text { of infections/year, episodes of severe pulmonary } \\
\text { infection, and days of antibiotics compared to PCF }> \\
\text { MEP }>\text { MIP. }\end{array}$ \\
\hline & & - $\mathrm{VC}<1.1$ Liter predicts severe lung infection \\
\hline Phillips et al ${ }^{17}$ & $\begin{array}{l}58 \text { DMD patient age } \\
>10 \text { years }\end{array}$ & $\begin{array}{l}\text { - } \mathrm{VC}<1 \mathrm{~L} \text { had a } 5 \text {-year survival rate of } 8 \% \text { without } \\
\text { adequate support for noninvasive respiration with a } \\
\text { median survival of } 3.1 \text { years. }\end{array}$ \\
\hline
\end{tabular}

\section{Gas Exchange Evaluation}

Gas exchange abnormalities can be seen at one point through arterial blood gas analysis (BGA) or measured continuously during waking or sleeping with various techniques like pulse oximetry, transcutaneous $\mathrm{CO}_{2}$ tension $\left(\mathrm{PtcCO}_{2}\right)$, dan end tidal $\mathrm{CO}_{2}$ tension $\left(\mathrm{PetCO}_{2}\right)$. Recurrent diurnal hypercapnia ( $\left.\mathrm{Pa} \quad \mathrm{CO}_{2}>45 \quad \mathrm{mmHg}\right)$ in infection-free lung indicates advanced respiratory failure and prompt initiation of NIV. ${ }^{18}$

\section{Respiratory Muscle Strength Evaluation}

Respiratory muscle strength can be measured by maximum static oral or nasal pressure evaluation. The maximum static mouth pressure measured with a mouthpiece connected to a manometer. Minimum measurement can be made accurately at the age of 6-7 years. ${ }^{5}$

Maximal inspiratory pressure (MIP or Pimax) is the average pressure that can be maintained for 1 second while patient takes a deep breath against the mouthpiece from residual volume (Mueller maneuver). Agustriani et al. examined MIP and MEP in healthy Indonesian children aged 8-12 years showing median MIP values for boys and girls were 60 and 55 $\mathrm{cmH}_{2} \mathrm{O}$ while those for MEP were 63 and 56 $\mathrm{cmH}_{2} \mathrm{O} .{ }^{19}$ Interpretation should should done serially for better result. Low MIP should be confirmed with supine VC and MIP to diagnose diaphragm weakness. Decrease in VC $25 \%$ 
with a decrease in MIP of $10-20 \%$ indicated diaphragmatic weakness. MIP also helps to differentiate between restrictive lung due to scoliosis or inspiratory muscle weakness. ${ }^{5,18}$

Maximal expiratory pressure (MEP) is the average pressure maintained for 1 second while the subject blows against the closed mouthpiece after maximum inspiration (Valsava maneuver). It reflects expiratory muscle power. In muscular dystrophy, MEP $>45-60 \mathrm{cmH}_{2} \mathrm{O}$ is required for effective cough. Under normal condition, MEP has a greater value than MIP. MEP < MIP indicates failure of expiratory muscles, a typical finding in SMA with diaphragm sparing. ${ }^{5,18}$

Nasal breath is an alternative if static oral pressure is difficult to measure due to i.e facial paresis. It is measured by breathing through nasal plug that is connected to manometer and can be done from the age of 5 . The subject performs a rapid sniff through nose producing sniff nasal inspiratory pressure (SNIP) from the FRC. It reflects the diaphragmatic strength. In 180 children aged 6-17 years, SNIFF measured FRC of $104 \pm 24 \mathrm{cmH}_{2} 0$ in boys and $93 \pm 23 \mathrm{cmH}_{2} \mathrm{O}$ in women with values similar to adults. Contraindication for measurement is nasal blockage. Longitudinal SNIP evaluation is useful for early detection in NMD patient younger than 5 years of age. ${ }^{20}$

\section{Functional Cough Evaluation}

Peak cough flow (PCF) value obtained from the simple peak flow meter. Objective examinations can be carried out on children starting at the age of 6-8 years. ${ }^{18}$ British Thoracic Society recommends routine $\mathrm{PCF}$ measurement in children aged $>12$ years. A cutoff $<270 \mathrm{~L} / \mathrm{min}$ indicates a weak cough. The critical PCF value is at $160 \mathrm{~L} / \mathrm{min}$ because it is the minimum value to effectively excrete secretions and maintain airway patency. PCF value $<160 \mathrm{~L}$ / min predictive for severe lung infection. In ventilated patients, PCF level $<160 \mathrm{~L} / \mathrm{min}$ predicts successful extubation. Children with
NMD $>12$ years and an ineffective cough $(<270$ $\mathrm{L} / \mathrm{min}$ ) need to be taught manual assisted cough (air stacking) techniques especially if they have worsening respiratory infections. PCF reevaluated with augmentation technique and called assisted-PCF. ${ }^{7,11}$

\section{Sleep Physiology Evaluation in NMD}

Overnight sleep monitoring has several components. The simplest is overnight pulse oxymetry overnight. Clinically significant hypoventilation unlikely to occur without $<93 \%$ desaturation. ${ }^{11}$ Single saturation monitoring is acceptable for screening in asymptomatic children when $\mathrm{CO}_{2}$ measurements are not available but is not applicable for symptomatic patients. Abnormal result should be followed by a more detailed examination at least oxycapnography. ${ }^{11}$

Oxycapnography is an overnight oximetry accompanied by $\mathrm{CO}_{2}$ continous testing both transcutaneously $\left(\mathrm{Tc} \mathrm{CO}_{2}\right)$ or end-tidal $\left(\mathrm{Et} \mathrm{CO}_{2}\right)$. Overnight Et- $\mathrm{CO}_{2}$ use nasal cannulae and less accurate in mouth breather. Confounder in Tc$\mathrm{CO}_{2}$ examination are underestimates in obesity cases. Periods of desaturation with hypercapnia in the active sleep phase indicate hypoventilation. ${ }^{9}$

Two consensuses said that patient with DMD and SMA, a full polysomnography (PSG) is recommended as gold standard sleep examination. BTS recommends performing abnormal overnight oximetry for screening in asymptomatic patients and abnormal findings are followed by a more detailed examination of at least oxycapnography. ${ }^{11} \mathrm{PSG}$ is the gold standard for SDB diagnosis and measurement of severity. It also plays role in titrating ventilator settings to improve gas exchange and reduce sleep fragmentation. Sleep monitoring with continuous EEG, electromyogram, and electrooculogram is supplemented by a comprehensive cardiorespiratory examination (oximetry with plethysmograph signals, $\mathrm{CO}_{2}$, ECG, breath pattern, nasal airflow, motion probe and video). ATS recommends annual 
sleep assessment in DMD ideally using PSG and $\mathrm{CO} 2$ measurement. $^{5}$

The American Academy of Sleep Medicine (AASM) defines nocturnal hypoventilation in adults as $\mathrm{PaCO}_{2}$ (or other substitution parameter) $>55 \mathrm{mmHg}$ with duration of $\geq 10$ minutes or increase sleep $\mathrm{PaCO}_{2}$ (or other substitution parameter) $\geq 10 \mathrm{mmHg}$ becoming $>50 \mathrm{mmHg}$ for $>10$ minutes compared to supine awake value. Pediatric nocturnal hypoventilation defined by $\mathrm{PaCO}_{2}$ (or other substitution parameter) $>50 \mathrm{mmHg}$ for $>25 \%$ of the total sleep time. Under these criteria at least a continuous measurement of $\mathrm{PaCO}_{2}$ during sleep is required. ${ }^{5}$

\section{Cardiorespiratory Fitness Evaluation in NMD}

Cardiorespiratory evaluation in NMD could be measured by 6 -minute walking test (6MWT) for ambulatoric patient. Young et al. tested reliability and validity of 6MWT compared to the incremental training test in SMA type 3 and 4. It is concluded that $6 \mathrm{MWT}$ is capable, safe, valid and reliable in these population. This test correlates with peak oxygen uptake representing exercise tolerance in ambulatory SMA patients, especially those who are weaker (walking $<300$ meters). The 6MWT test also illustrates an important aspect of fatigue in NMD by comparing the distance traveled in the first minute and the last minute. The minimum important change (MIC) was found to be 2844 meters. $^{21}$ McDonald et al. performed a modified 6-minute walk test in DMD patients aged 4-12 years with controls. The walking distance was significantly reduced due to controls stride decrease. Safety aspect is priority because namely healthy children and DMD population, both experience high fall rate so that safety chasers are needed. Verbal encouragement is also used more frequent (every 15 seconds). ${ }^{22}$

\section{CONCLUSION}

Respiratory assessment in childhood neuromuscular disease is important to reduce comorbidity and complication. Assessment should focus on respiratory function and factor that may influence it such as cardiac, musculoskeletal, nutritional, and swallowing. Follow up interval and respiratory evaluation component determined by speed of progression and nature of each neuromuscular disease. Abnormal result from the assessment as an indicator for prompt treatment to prevent complication and improve survival rate such as breathing technique, airway clearance technique or use of respiratory orthosis such as non-invasive ventilation or mechanical insufflation-exsufflation (MIE). Intervention should aim to improve quality of life and prolong survival in children with NMD.

\section{REFERENCES}

1. Askanas V, King Engel W. Update on neuromuscular diseases: Pathology and molecular pathogenesis. Biochim Biophys Acta - Mol Basis Dis 2015; 1852(4): 561-2.

2. Pfeffer G, Povitz M. Respiratory management of patients with neuromuscular disease: current perspectives. Degener Neurol Neuromuscul Dis 2016; 6: 111-8.

3. Tortora G, Derrickson B. The Respiratory System. In: Principles of Anatomy \& Physiology. 15th ed. United States: Wiley; 2017.

4. Malik V, Smith D, Lee-Chiong $T$. Respiratory physiology during sleep. Sleep Med Clin 2012; 7(3): 497-505. 
5. Voulgaris A, Antoniadou M, Agrafiotis M, Steiropoulos P. Respiratory involvement in patients with neuromuscular diseases: A narrative review. Pulm Med 2019; 2019.

6. Farrero E, AntónA, Egea CJ. Guidelines for the management of respiratory complications in patients with neuromuscular disease. Arch Bronconeumol 2013; 49(7): 306-13.

7. Chiang J, Mehta K, Amin R. Respiratory diagnostic tools in neuromuscular disease children. Children 2018; 5(6): 78.

8. Bach J, Dikeman K, Gaydos J, Guylas A, Haber I. Management of Patients With Neuromuscular Disease. 1st ed. Hanley \& Belfus. United States: Hanley \& Belfus; 2004.

9. Arnold D, Kassar D, Kissel J. Spinal muscular atrophy: diagnosis and management in a new therapeutic era. Muscle Nerve 2015; 51(2): 157-67.

10. Engel-hoek L Van Den, Groot IJM De, Swart BJM De, Erasmus CE. Feeding and swallowing disorders in pediatric neuromuscular diseases. J Neuromuscul Dis 2015; 2: 357-69.

11. Hull J, Aniapravan R, Chan E. British thoracic society guideline for respiratory management of children with neuromuscular weakness. Thorax 2012; 67.

12. Birnkrant DJ, Bushby $\mathrm{K}$, Bann $\mathrm{CM}$, Alman BA. Diagnosis and management of duchenne muscular dystrophy, part 2 . Lancet Neurol 2018; 17(4): 347-61.

13. Mercuri E, Finkel RS, Muntoni F. Diagnosis and management of spinal muscular atrophy: Part 1. Neuromuscul Disord 2018; 28(2): 103-15.
14. Grippi M, Elias J, Fishman J, Kotloff R, Pack A, Senior R. Fishman Pulmonary Disease and Disorders. 5th ed. United States: McGraw-Hill; 2015.

15. Ragette R, Mellies U, Schwake C, Voit T, Teschler H. Patterns and predictors of sleep disordered breathing in primary myopathies. Thorax 2002; 57(8): 724-8.

16. Dohna-Schwake C, Ragette R, Teschler H, Voit T, Mellies U. Predictors of severe chest infections in pediatric neuromuscular disorders. Neuromuscul Disord 2006; 16(5): $325-8$.

17. Phillips MF, Quinlivan RCM, Edwards RHT, Calverley PMA. Changes in spirometry over time as a prognostic marker in patients with duchenne muscular dystrophy. Am J Respir Crit Care Med 2002; 164(12): 2191-4.

18. Hammer J, Eber E. Paediatric Pulmonary Function Testing. 1st ed. Karger Publishing; 2005. 299 p.

19. Agustriani V, Wahyuni L, Paulus A, Herqutanto. Maximum inspiratory pressure dan maximum expiratory pressure pada anak Indonesia sehat usia 8-12 tahun di Jakarta; 2019.

20. Nève V, Cuisset JM, Edmé JL. Sniff nasal inspiratory pressure in the longitudinal assessment of young DMD children. Eur Respir J 2013; 42(3): 671-80.

21. Dunaway Young S, Montes J, Kramer SS. Six-minute walk test is reliable and valid in spinal muscular atrophy. Muscle Nerve 2016; 54(5): 836-42.

22. McDonald C, Henricson E, Han J. The 6-minute walk test as a new outcome measure in duchenne muscular dystrophy. Muscle Nerve 2010; 41: 500-10. 